\title{
PENGARUH PIJAT OKSITOSIN TERHADAP PENGELUARAN AIR SUSU IBU (ASI) PADA IBU POST SECTIO CAESARIA
}

\author{
Etri Yanti ${ }^{1}$ \\ Stikes Syedza Saintika Padang \\ Email : yantietri84@yahoo.co.id \\ Dwi Christina Rahayuningrum ${ }^{2}$ \\ Stikes Syedza Saintika Padang \\ Email : noeninksweet@gmail.com
}

\begin{abstract}
ABSTRAK
Latar belakang :Air susu ibu (ASI) menjadi makanan pertama dan terbaik yang harus diberikan untuk bayi karena mengandung zat gizi yang sangat dibutuhkan dalam proses pertumbuhan dan perkembangan kecerdasan anak. Salah satu penyebab kegagalan dalam pemberian ASI adalah belum keluarnya ASI setelah ibu melahirkan, Pengeluaran ASI dapat dipercepat dengan tindakan non farmakologi yaitu dengan melalui pijat oksitosin yang dapat dilakukan dengan cara memijat area di sekitar punggung (vertebra pars thoratica) untuk merangsang keluarnya ASI yang dapat mengaktifkan dua hormon yaitu hormone prolaktin dan hormon oksitosin untuk pengeluaran ASI Tujuan penelitian ini untuk mengetahui Pengaruh Pijat Oksitosin terhadap Pengeluaran ASI pada Ibu Post Sectio Caesarea. Metode : penelitian ini merupakan penelitian pra eksperimen dengan pendekatan one group pretest posttest. Populasinya adalah ibu-ibu post partum sectio caesar yang berjumlah 16 orang. Teknik sampel menggunakan purposive sampling, Pengumpulan data menggunakan lembar observasi waktu pengeluaran kolostrum, Data dianalisis dengan uji T Independen. Hasil : penelitian didapatkan rata-rata pengeluaran ASI sebelum dilakukan Pijat Oksitosin 0,34 cc, dan rata - rata Pengeluaran ASI sesudah dilakukan Pijat Oksitosin adalah 1,75 cc. Berdasarkan uji statistic didapatkan $p$ Value $=0,000(p \leq 0,05)$ yang berarti ada Pengaruh antara Pijat Oksitosin dan pengeluaran ASI. Kesimpulan : Implikasi penelitian adalah pijat oksitosin mempengaruhi kecepatan pengeluaran kolostrum, sehingga rumah sakit dapat mengaplikasikan SPO pijat oksitosin yang sebaiknya dilakukan pada 12 jam pertama post partum.
\end{abstract}

Kata Kunci : Pijat Oksitosin, Pengeluaran ASI, post sectio Caesarea

\begin{abstract}
Mother milk (breast milk) is the first and best food that a baby should provide because it contains much-needed nutrients in the growing and developing process of a child's intelligence. One cause of the failure of breast-feeding is that it hasn't been breast-feeding since the mother gave birth, Breastfeeding secretions can be accelerated by a nonpharmacological massage that can be done by massaging an area around the back (the thoratica pars thoratica) to stimulate an area of breast milk that triggers two hormones, a hormone hormone hormone prolacing and oxytocin for breastfeeding purposes, to identify the effects of oxytocin massage on the mothers' post sectional discharge. This method of research represents a preexperiment with the approach of one group pretest posttest. The population was the 16th-century Caesar post wives. Sample techniques use an adhesive sampling, data
\end{abstract}


Etri Yanti : Pengaruh Pijat Oksitosin Terhadap Pengeluaran Air Susu Ibu (ASI) pada Ibu Post Sectio Caesaria

collection uses a colostrum exhaust time sheet, data is analyzed with an independent $t$-test. The results were obtained on average breast costs before 0.34 cc oxytocin massage, and the average - the cost of breast milk after oxytocin is 1.75 CC. The implications of research are that oxytocin massage affects the rate of consumption of colostrum, so the hospital can apply the oxytocin massage standart operational procedure that should be performed in the first 12 hours of post partum.

Keywords: oxytocin massage, breast laceration, post section caesarea

\section{PENDAHULUAN}

Air Susu Ibu (ASI) eksklusif atau lebih tepat pemberian ASI (Air Susu Ibu) secara eksklusif adalah bayi hanya diberi ASI saja, sejak usia 30 menit post natal (setelah lahir) sampai usia 6 bulan tanpa tambahan cairan lain (Walyani \& Purwoastuti, 2015). Air susu ibu (ASI) menjadi makanan pertama dan terbaik yang harus diberikan untuk bayi karena mengandung zat gizi yang sangat di dibutuhkan dalam proses pertumbuhan dan perkembangan kecerdasan anak (Prasetyono, 2012)

Pemberian ASI eksklusif mencegah 1,4 juta kematian anak berusia dibawah umur lima tahun dinegara-negara berkembang (Fatmah, 2014). Anak sebagai generasi penerus bangsa yang merupakan aset yang sangat berharga berhak mendapatkan perlindungan dengan diberikan nutrisi terbaik yang mengandung zat gizi untuk pertumbuhan dan perkembangannya, hal ini ditegaskan dalam Permenkes 450 tahun 2004.

Produksi ASI dan keberhasilan menyusui ditentukan oleh dua hal yaitu reflek prolaktin dan reflek oksitosin. Reflek prolaktin didasarkan pada kondisi stress dan pengaruh psikis, anastesi, operasi dan rangsangan puting susu yang mempengaruhi rangsangan hormonal untuk memproduksi ASI. Sewaktu bayi menyusu di dalam putting susu terdapat banyak ujung saraf sensoris. Bila ini dirangsang timbul impuls yang menuju hipotalamus selanjutnya kelenjar hipofisis bagian depan sehingga kelenjar ini mengeluarkan hormon prolaktin sehingga ASI diproduksi. Pada akir kehamilan hormon prolaktin memegang peran untuk membuat kolostrum, tetapi jumlah kolostrum terbatas dikarenakan aktivitas prolaktin dihambat oleh estrogen dan progesteron yang masih tinggi (Heryani, 2010).

Inisiasi menyusui dini (IMD) adalah meletakan bayi diatas perut dan dada ibunya perlahan bayi dapat merangkak kearah puting susu ibu dan menyusu sendiri, bau air ketuban yang masih menempel di tangan bayi sama dengan bau cairan ASI. Bau inilah yang membimbing bayi merangkak menghentakkan kepala ke dada ibu, sampai akhirnya menemukan payudara, menjilati putting susu ibu membuka mulutnya lebar-lebar dan mulai menyusu, pada saat inilah bayi mendapatkan kolostrum ASI pertama. IMD memberikan motivasi yang sangat besar dan mengurangi kesulitan ibu untuk menyusui (Sri Astuti, Raden Tina Dewi Judistiani, Lina Rahmawati, 2015).

Keberhasilan IMD pada operasi caesarea beberapa penelitian antara lain sekitar $50 \%$ bayi dapat merespon IMD dalam waktu 30 menit pada ibu yang 
melahirkan dengan operasi caesarea, Hasil penelitia yang telah dilakukan di RS St. carolus tahun 2008 pada 276 bayi adalah sebesar 75\% (209 bayi). IMD kelahiran spontan sebesar $82 \%$ persalinan vakum sebesar $44 \%$ dan pada persalinan caesarea sebanyak 59 $\%$ (Sri Astuti, Raden Tina Dewi Judistiani, Lina Rahmawati, 2015)

Kendala yang terjadi pada inisiasi menyusui dini (IMD) yang tidak berhasil bisa di sebabkan oleh faktor ibu dan juga bayi nya. Penyebab dari ibunya adalah kondisi fisik yang lemah karena menjalani proses persalinan serta kondisi psikologis Ibu, anastesi, operasi yang dapat menyebabkan terhambat kerja oksitosin, sedangkan penyebab dari bayinya yaitu kurang mampu dan peka nya bayi beradaptasi dengan lingkungan sekitar contoh nya mencari puting susu ibu tersebut (E. S. Walyani \& Purwoastuti, 2016)

Masalah dalam pemberian ASI di Indonesia berdasarkan hasil analisis Riskesdas 2010 antara lain persentase insiasi menyusui dini kurang dari satu jam setelah lahir sebesar 29,3\% : Sebagain besar bayi mulai disusui setelah lahir sebesar 29,3\%. Sebagian besar bayi mulai disusui pada kisaran waktu 1-6 jam setelah lahir. Persentase proses menyusui bayi setelah 48 jam sebesar $11,1 \%$ serta persentase pemberian kolostrum oleh ibu kepada bayinya cukup baik yaitu sebesar 74,7\% (Sri Astuti, Raden Tina Dewi Judistiani, Lina Rahmawati, 2015).

Hasil riset kesehatan dasar Indonesia tahun 2013 menunjukkan bahwa di Indonesia persentase pemberian ASI dalam 1 jam setelah bayi lahir adalah $34,5 \%$. Walaupun persentase ini telah meningkat dari tahun 2010 sebesar 29,3\% tetapi angka ini belum membahagiakan. Hasil yang diperoleh Negara kita masih jauh dibandingkan Negara serumpun di Asia Tenggara menurut laporan world breasfeeding trends iniative (WBTi), insisi menyusui dini (IMD) di Indonesia masih kalah tertinggal dari Bangladesh,Vietnam, Philipina (Suleiman \& Abdul Moin, 2015)

Data teori jurnal (Fahlilani Zamzara, 2018) tentang pemberian tindakan Pengeluaran ASI pada Ibu sectio caesarea mungkin belum mengeluarkan ASI dalam waktu 24 jam pertama setelah melahirkan kadangkala hingga dalam waktu 48 jam walaupun demikian bayi tetap diletakan pada payudara Ibu untuk membantu merangsang pengeluaran ASI pertama. Persalinan sectio caesarea dalam pengeluaran ASI terjadi antara 2-3 hari (48jam-72 jam) yang di pengaruhi oleh beberapa faktor antara lain stress, anastesi, operasi caesar kehilangan banyak darah lebih dari $500 \mathrm{ml}$ biasanya terjadi ketika ibu mengalami perdarahan setelah melahirkan (Arinda, 2018).

Hasil penelitian menunjukan bahwa lamanya pengeluaran ASI pada ibu post SC 48,6\% kurang dari 24 jam dan $51,4 \%$ pengeluaran ASI terjadi setelah 24 jam (Noviani, 2016). Ibu setelah melahirkan sectio caesarea membutuhkan waktu untuk pemulihan akibat nyeri yang ditimbulkan. Selama menunggu masa pemuliahan ini akan menyebabkan proses menyusui tertunda. Akibat dari proses menyusui yang tertunda ini bayi akan mengalami kekurangan nutrisi, hubungan emosional bayi dan Ibu terganggu dan stimulasi kontraksi uterus menjadi berkurang (Smith, 2006).

Beberapa terapi farmakologi dan non farmakologi telah banyak diteliti dan digunakan untuk mempertahankan produksi ASI, Terapi farmakologi untuk meningkatkan produksi ASI di antaranya adalah obat metoklopramid, 
Etri Yanti : Pengaruh Pijat Oksitosin Terhadap Pengeluaran Air Susu Ibu (ASI) pada Ibu Post Sectio Caesaria

Domperidon, Sulfirid, chlorpromazin, dan injeksi Oksitoksin. Selain itu injeksi oksitosin tidak direkomendasikan pada ibu dengan SC karena dapat mengakibatkan dan merangsang kontraksi setelah operasi sectio caesarea (SC).Injeksi oksitosin dan pijat oksitosin memiliki persamaan diantarnaya adalah yaitu menseksresi hormon oksitosin sebagai hormon pengeluaran Air Susu ibu. Sedangkan terdapat perbedaan yaitu pijat oksitosin merangsang hormon prolaktin dan oksitosin serta dilakukan dalam pemijatan antara tulang belakang costae 5 dan 6 sedangkan injeksi oksitosin adalah selain untuk produksi ASI fungsi dari injeksi oksitosin ini adalah memicu dan memperkuat kontraksi pada otot rahim (jannah, 2014 dan hakimi, 2010).

Beberapa penelitian menunjukkan bahwa pendekatan non farmakologis dapat dilakukan pada ibu yang bermasalah pada pengeluaran ASI pada post sectio caesarea yaitu meliputi: Pijat Oksitosin pada ibu yang post partum sectio caesarea 12 jam pertama yang belum mengeluarkan kolostrum. Pijat oksitosin adalah pemijatan pada sepanjang tulang belakang sampai tulang costae kelima keenam dan merupakan usaha untuk merangsang hormon prolaktin dan oksitosin (Widya, 2016).

Menyusui dini di jam-jam pertama kelahiran jika tidak dilakukan oleh ibu akan menyebabkan proses menyusu tertunda, maka alternatif yang dapat dilakukan adalah pijat oksitoksin. Tindakan tersebut dapat membantu memaksimalkan reseptor oksitosin dan meminimalkan efek samping dari tertundanya proses menyusui oleh bayinya (Evariny, 2008). Efek nya si bayi tidak mendapatkan bahan makanan yang baik karena ASI sudah mencakup seluruh zat gizi yang diperlukan bayi untuk kehidupan 6 bulan pertama si bayi dan ASI untuk perkembanga si bayi (Sri Astuti, Raden Tina Dewi Judistiani, Lina Rahmawati, 2015).

Menstimulasii refleks oksitosin penting dalam menyusui atau memberikan ASI. Reflek oksitosin membuat aliran ASI dari payudara menjadi lancar, sehinga menyusui semakin lancar dan mengurangi bendungan saluran ASI, juga dapat membuat rileks pada ibu dan melancarkan aliran syaraf serta saluran ASI pada kedua payudara (Sri Astuti, Raden Tina Dewi Judistiani, Lina Rahmawati, 2015).

Menurut hasil penelitian yang dilakukan oleh Rezza dkk (2015) tentang pengaruh pijat oksitosin terhadap waktu pengeluaran kolostrum ibu post partum sectio caesarea, hasil penelitian menunjukkan ada pengaruh pijat oksitosin terhadap waktu pengeluaran kolostrum pada ibu post partum sectio caesarea dengan nilai $\mathrm{p}=$ $0,026$ ( $\mathrm{p} \leq 0,05)$. Menurut Siti dkk (2016) yang berjudul pengaruh pijat oksitosin dan mobilisasi dini terhadap pengeluaran kolostrum ibu post sectio caesarea, hasil penelitian menunjukan $(\mathrm{p}=0,0001)$ bahwa pijat oksitosin berpengaruh lebih signifikan terhadap pengeluaran kolostrum). Menurut penelitian lain yang dilakukan oleh Azizah dkk (2016) yang berjudul pengaruh pijat oksitosin terhadap pengeluaran ASI pada ibu postpartum di BPM Pipin Heriyanti Yogyakarta hasil penelitian menunjukkan ada pengaruh pijat oksitosin terhadap pengeluaran ASI pada ibu postpartum dengan nilai $(\mathrm{p}<0,05)$.

Berdasarkan data tahun 2017 bulan Januari - Desember yang didapat dari bangsal kebidanan RST didapatkan jumlah ibu sectio caesarea 518 orang. Data dari bulan Januari-Maret 2018 
jumlah ibu sectio caesarea 140 orang di bangsal kebidanan Rumah Sakit Tk. III Dr. Reksodiryo Padang.

Tujuan Penelitian dari penelitian ini untuk mengetahui Pengaruh Pijat Oksitosin terhadap Pengeluaran Air Susu Ibu pada Ibu Post Sectio Caesarea di Rumah Sakit Tk. 111 dr. Reksodiwiryo Padang.

\section{METODE PENELITIAN}

Jenis penelitian ini menggunakan desain praeksperimen design dengan pendekatan one group pretest posttest (Notoadmojo, 2012). Desain penelitian yang melakukan observasi (pengukuran) sebelum dan sesudah diberikan perlakuan pada satu kelompok (dilakukan pengukuran pengeluaran ASI Ibu post SC sebelum dan sesudah dilakukan pijat oksitosin). Penelitian ini dilaksanakan di bangsal kebidanan Rumah Sakit Tk. $111 \mathrm{dr}$. Reksodiwiryo Padang.

Populasi pada penelitian ini adalah ibu post sectio caesarea (SC) di Bangsal Kebidanan RST Reksodiwiryo Padang dengan jumlah ibu post sectio caesarea 140 orang bulan Januari - Maret 2018 (RST Reksodiwiryo Padang 2018). Sampel dalam penelitian ini adalah Ibu yang melahirkan post sectio caesarea (SC) di Bangsal kebidanan RST Reksodiwiryo Padang tahun 2018 yang berjumlah 16 orang dengan teknik purposive sampling .

Teknik pengumpulan data dilakukan secara langsung (observasi) dengan mengukur pengeluaran ASI ibu post sectio caesarea sebelum dan sesudah di lakukan pijat oksitosin. Cara melakukan penelitian : Melakukan pijat oksitosin pada responden dua kali sehari selama 5 menit dimulai pada 12 jam post sectio caesarea sampai hari ke 5 post sectio caesarea di Rumah sakit Tk.lll dr. Reksodiwiryo Padang .
Dan mengukur produksi ASI responden sesudah pijat oksitosin dilakukan pada hari ke 5 .

\section{HASIL PENELITIAN}

A. Univariat

Tabel 1. Rata - rata Pengeluaran Air Susu sebelum di lakukan Pijat Oksitosin

\begin{tabular}{cccc}
\hline & $\begin{array}{c}\text { M } \\
\text { e }\end{array}$ & $\begin{array}{c}\text { Stan } \\
\text { dar } \\
\text { a }\end{array}$ & $\begin{array}{c}\text { M } \\
\text { in }\end{array}$ \\
& $\begin{array}{c}\text { nevi } \\
\text { asi } \\
\text { (SD) }\end{array}$ & $\begin{array}{c}\text { M } \\
\text { ak } \\
\text { S }\end{array}$ \\
\hline $\begin{array}{c}\text { Pengeluaran } \\
\text { ASI sebelum }\end{array}$ & 0. & 0.37 & $0-$ \\
$\begin{array}{c}\text { dilakukan pijat } \\
\text { oksitosin }\end{array}$ & 3 & 5 & 1 \\
\hline
\end{tabular}

Tabel 2.Rata- rata Pengeluaran Air Susu sesudah di lakukan Pijat Oksitosin

\begin{tabular}{ccccc}
\hline & $\begin{array}{c}\text { Me } \\
\text { an }\end{array}$ & $\begin{array}{c}\text { Stan } \\
\text { dar } \\
\text { Vevia } \\
\text { Si }\end{array}$ & $\begin{array}{l}\text { Min - } \\
\text { Maks } \\
\text { (SD) }\end{array}$ & \\
\hline Pengelua & & & & \\
ran ASI & & & & \\
sesudah & & & & \\
dilakuka & 1.75 & 1.000 & 0 & -3 \\
n pijat & & & & \\
oksitosin & & & & \\
\hline
\end{tabular}

B. Analisis Bivariat

Tabel 3. Pengaruh Pijat Oksitosin terhadap Pengeluaran Air Susu Ibu pada Ibu Post Sectio Caesarea (SC)

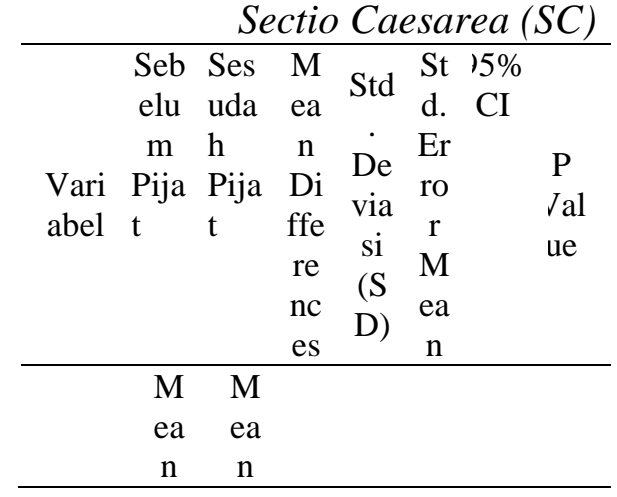


Etri Yanti : Pengaruh Pijat Oksitosin Terhadap Pengeluaran Air Susu Ibu (ASI) pada Ibu Post Sectio Caesaria

\begin{tabular}{lcccccccc}
\hline Peng & 0. & 1. & & & & - & \\
eluar & 34 & 75 & - & .90 & .2 & 1.89 & 0.0 \\
an & & & 1.4 & 8 & 27 & $1--$ & 00 \\
ASI & & & 06 & & & 923 & \\
\hline
\end{tabular}

\section{PEMBAHASAN}

\section{Pengeluaran Air Susu Ibu sebelum diberikan Pijat Oksitosin}

Hasil penelitian menunjukkan bahwa rata-rata Pengeluaran Air Susu Ibu sebelum dilakukan Pijat Oksitosin (pretest) 0,34 dengan standar deviasi 0,375. Pengeluaran ASI sebelum dilakukan Pijat Oksitosin dengan nilai tertinggi adalah $1 \mathrm{cc}$ dan terendah adalah $0 \mathrm{cc}$.

Penelitian ini sejalan dengan penelitian Mera dkk, 2016 tentang Pengaruh Pijat Oksitosin terhadap Produksi ASI ibu menyusui di Puskesmas Plus Mandiangin Bukitinggi. Dengan hasil rata-rata sebelum di berikan intervensi adalah 7,05 dengan standar deviasi adalah 0,740 .

ASI Eklusif adalah Bayi yang hanya diberi ASI saja sejak usia 30 menit post natal (setelah lahir) sampai usia 6 bulan tanpa tambahan cairan lain seperti susu formula,air dll (Elisabeth, 2015). Fisiologi laktasi terjadi selama kehamilan hormon prolaktin dari plasenta meningkat tetapi ASI biasanya belum keluar karena dihambat oleh kadar estrogen yang tinggi. Pada saat inilah mulai terjadi sekresi ASI yang di pengaruhi oleh dua refleks pada ibu yang sangat penting dalam proses laktasi (E. S. Walyani \& Purwoastuti, 2016)

Pada ibu yang melahirkan normal IMD (Inisiasi Menyusui Dini) dalam 30 menit pertama kelahiran, menitmenit pertama bayi menunjukkan kemampuan yang menabjukan, ketika di letakan diatas perut atau dada Ibunya, perlahan bayi dapat merangkak ke arah puting susu Ibu dan menyusu sendiri. Setiap bayi mempunyai kemampuan untuk menemukan payudara Ibunya dan mengambil minum pertamanya dengan kemampuannya sendiri. volume ASI dalam keadaan normal dapat diperoleh pada lima menit pertama rata- rata bayi yang menyusui selama 15- 25 menit dimana bayi normal memerlukan 160165 cc ASI per kilogram berat badan perhari dengan volume ASI Hari pertma 10 cc (Sri Astuti, Raden Tina Dewi Judistiani, Lina Rahmawati, 2015)

Pada Ibu yang melahirkan Sectio Caesarea (SC) di lakukan dalam 30 menit pada ibu yang mrlahirkan SC, penelitian yang telah dilakukan carolus, 2008 pada 276 bayi keberhasilan IMD (Inisiasi Menyusui Dini) pada kelahiran spontasn sebesar $82 \%$ dan pada persalinan operasi SC sebesar 59\%. Penelitan ini membuktikan bahwa inisiasi menyusui dini membantu dalam keberlangsungan pemberian ASI Eklusif dan juga produksi ASI pada Ibu Sectio Caesarea (SC) di tentukan juga dari psikologis ibu yang mempengaruhi hormon prolaktin dan oksitosin dalam produksi ASI (Sri Astuti, Raden Tina Dewi Judistiani, Lina Rahmawati, 2015).

Menurut analisa peneliti Pengeluaran Air Susu Ibu post Sectio Caesarea (SC) banyak terganggu karena faktor ketenangan jiwa dan pikiran Ibu yang tidak baik sebelum dan setelah post Sectio Caesarea atau keadaan psikologi ibu yang tertekan sedih dan tegang menyebabkan terjadinya penurunan volume ASI serta yang menghambat kerja hormon oksitosin dan prolaktin, faktor lain yang menyebabakn ASI ibu sedikit keluar yaitu kurang nya bayi menyusu pada ibu sehingga menurunkan volume ASI ibu dapat juga dipengaruhi oleh umur responden dilihat dari hasil 
karakteristik umur responden dari 9 responden $(52,2 \%)$ dengan umur $<30$ tahun banyak mengalami produksi ASI yang sedikit.

\section{Pengeluaran Air Susu Ibu setelah dilakukan Pijat Oksitosin}

Dari penelitian menunjukkan bahwa rata-rata Pengeluaran Air Susu Ibu ( postes) adalah 1,75 dengan standar deviasi 1,000. Pengeluaran ASI tertinggi adalah $3 \mathrm{cc}$ dan terendah adalah 0 cc. Penelitian ini sejalan dengan penelitian yang dilakukan Rezza tentang Pengaruh Pijat Oksitosin terhadap waktu Pengeluaran Kolostrum Ibu post Partum Sectio Caesarea (SC) dengan rata-rata sesudah di Pijat Oksitosin adalah 1,70.

Pijat Oksitosin adalah Pemijatan pada sepanjang tulang belakang sampai tulang costae kelima dan keenam dan merupakan upaya meningkatkan kesehatan bayi dan memberikan dukungan pada ibu Sectio Caesarea (SC) untuk berkelanjutan dalam memberikan ASI secara eklusif sampai usia bayi 6 bulan. Pemijatan dilakukan 2 kali sehari selam 5 hari dengan waktu 5 menit (Latifah \& Wahid, 2015).

Menstimulasi Reflek Oksitosin merupakan stimulant sel mioepitel yang paten yang memompa Air Susu dari sinus laktiferus ke luar puting hingga sampai ke mulut bayi. Keluarnya air susu ini meningkatkan refleks isapan bayi lebih lanjut menyebabkan lebih banyak oksitosin yang disekresi, namun demikian stress pada Ibu bisa menghinhibisi dengan kuat refleks pengeluaran Air Susu sehingga stres pada Ibu merupakan salah satu kegagalan laktasi ( Jeremy, 2005).

Menurut Analisa peneliti faktor yang mempengaruhi produksi ASI selain kondisi psikologis ibu yang terganggu. Pada ibu yang baru saja melewati proses persalinannya sering merasa kelelahan dan stres akibat rasa sakit yang dialami saat menjalani persalinanya serta terjadinya ketegangan otot, penyebab lainnya juga karna faktor pola istirahat ibu yang kurang karna dengan Ibu yang melahirkan anak pertama dan bayinya rewel dan intensitas menyusu bayi yang kurang menyebabkan ibu kurang istirahat dan mempengaruhi pengeluaran ASI. Setelah dilakukan Pijat Oksitosin yang mulai diberikan hari pertama sampai hari ke lima pada Ibu post Sectio caesarea (SC), memberikan efek yang bermakna terhadap pengeluaran ASI pada ibu post Sectio Caesarea (SC) pemijatan dilakukan 2 kali sehari selam 5 hari dan Pijat Oksitosin dilakukan dalam rentang waktu 5 menit.

\section{Pengaruh Pijat Oksitosin terhadap Pengeluaran ASI pada Ibu post Sectio Caesarea}

Hasil penelitian ini menunjukkan bahwa rata-rata pengeluaran Air Susu Ibu post Sectio Caesarea (SC) adalah 1.406 dengan standar deviasi 908 . Hasil uji statistic didapatkan $\mathrm{p}$ Value 0,000 ( $\mathrm{p} \leq 0.05$ berarti ada pengaruh Pijat Oksitosin terhadap pengeluaran Air Susu Ibu pada Ibu post Sectio Caesarea (SC) Di Rumah Sakit Tk. 111 dr. Reksodiwiryo Padang Tahun 2018.

Penelitian ini sejalan dengan penelitian yang dilakukan oleh (Delima, Arni, \& Rosya, 2016) tentang Pengaruh Pijat Oksitosin terhadap Peningkatan Produksi ASI Ibu menyusui Puskesmas Plus Mandiangin Bukitinggi, dimana berdasarkan hasil penelitian menunjukkan bahwa perbedaan rata-rata pengeluaran ASI sebelum di pijat oksitosin adalah 7,05 dengan standar deviasi 0,740 dan rata rata pengeluaran ASI setelah di pijat oksitosin adalah 9,00 dengan standar 
Etri Yanti : Pengaruh Pijat Oksitosin Terhadap Pengeluaran Air Susu Ibu (ASI) pada Ibu Post Sectio Caesaria

deviasi 1,183. Hasil uji statistic didapatkan $\mathrm{p}$ Value 0,000 disimpulakan bahwa ada efek Pijat Oksitosin terhadap Peningkatan Produksi ASI ibu menyusui di Puskesmas Plus Mandiangin Bukitinggi 2016.

Hasil penelitian diatas sesuai dengan pendapat (Fahlilani Zamzara, 2018) dimana Pijat Oksitosin adalah tindakan pemijatan yang dilakukan sepanjang tulang vertebra sampai costae kelima, keenam dan upaya untuk merangsang hormon prolaktin dan oksitosin yang bekerja pada stimulus pada vertebra sampai costa 5-6 sehingga meningkatkan rangsangan hipofise posterior untuk mengeluarkan hormon oksitosin.

Proses laktasi di pengaruhi oleh dua refleks yaitu reflek prolaktin reflek (let down reflekx) . Refleks prolaktin bekerja sewaktu bayi menyusu ujung saraf peraba yang terdapat pada putting terangsang lalu memicu hipofise anterior untuk mengeluarkan hormon prolaktin ke dalam darah. Jumlah prolaktin yang disekresi dan jumlah susu yang di produksi berkaitan dengan stimulus isapan yaitu frekwensi intensitas dan lamanya bayi menghisap ((E. S. Walyani \& Purwoastuti, 2016)).

Refleks (Let Down Reklex) adalah rangsangan yang ditimbulkan oleh bayi saat menyusui selain mempengaruhi hipofise posterior mengeluarkan hormon oksitosin, dimana setelah oksitosin dilepas ke dalam darah memacu otot-otot polos yang mengelilingi alveoli dan duktus berkonsentrasi sehingga memeras air susu dari alveoli duktus dan sinus menuju putting susu. Reflek ini di pengaruhui oleh kejiwaan Ibu ( elysabeth siwi Walyani, 2016)

Seseorang yang dalam keadaan tertekan sedih dan tegang mempengaruhi hormon oksitosin untuk memproduksi ASI dan menyebabkan volume ASI terhambat dan sedikit(E. S. Walyani \& Purwoastuti, 2016). Apabila kondisi Ibu terlalu capek kurang istirahat volume ASI juga berkurang ( Damai, 2011). Pernyataan tersebut menunjukkan bahwa pijat oksitosin adalah pemijatan pada sepanjang tulang belakang sampai tulang costae kelima dan keenam dan usaha untuk merangsang dan usaha untuk merangsang hormon prolaktin dan oksitosin.

Menurut Asumsi peneliti, dengan mempelajari dari berbagai teori dan hasil penlitian yang telah diuraiakan diatas, Pijat Oksitosin berpengaruh dalam pengeluaran Air Susu Ibu post Sectio Caesarea (SC). Karena Pijat Oksitosin merangsang dua refleks yang bekerja pada ibu yang melahirkan yaitu refleks proklatin dan refleks Oksitosin selain itu hormon ini akan terhambat jika psikologi Ibu terganggu yang mengakibatkan volume ASI terhambat. Hasil penelitian menunjukkan setelah dilakukan Pijat Oksitosin yang mulai diberi hari pertama sampai hari kelima memberikan efek yang bermakna terhadap pengeluaran Air Susu Ibu post Sectio Caesarea.

\section{KESIMPULAN}

Pada penelitian ini dapat disimpulkan bahwa terdapat Pengaruh Pengeluaran Air Susu Ibu pada Ibu post Sectio Caesarea (SC) sebelum dan sesudah dilakukan Pijat Oksitosin

\section{DAFTAR PUSTAKA}

Delima, M., Arni, G., \& Rosya, E. (2016). PENGARUH PIJAT OKSITOSIN TERHADAP PENINGKATAN PRODUKSI ASI IBU MENYUSUI DI PUSKESMAS PLUS MANDIANGIN. Jurnal Ipteks Terapan. 
https://doi.org/10.22216/jit.2015.v 9i4.1238

Fahlilani Zamzara, R. (2018). PENGARUH PIJAT OKSITOSIN TERHADAP WAKTU PENGELUARAN KOLOSTRUM IBU POST PARTUM SECTIO CAESARIA. Journal of Health Sciences.

https://doi.org/10.33086/jhs.v8i2.2 10

Latifah, J., \& Wahid, A. (2015). Perbandingan Breast Care Dan Pijat Oksitosin Terhadap Produksi Asi Pada Ibu Post Partum Normal. Perbandingan Breast Care Dan Pijat Oksitosin DK.

Noviani, D. (2016). PENGARUH MENYUSUI DINI TERHADAP LAMANYA PENGELUARAN AIR SUSU IBU POST SECTIO CAESAREA. 2-TRIK: TunasTunas Riset Kesehatan.

Sri Astuti, Raden Tina Dewi Judistiani, Lina Rahmawati, A. I. S. (2015). Asuhan Kebidanan Nifas \& Menyusui. In Bandung: Erlangga. https://doi.org/10.1017/CBO9781 107415324.004

Suleiman, A., \& Abdul Moin, S. N. (2015). International Baby Food Action Network Asia Unnual Report. 2010. Diakses oleh Feritani pada tanggal 18 Mei 2018 pukul 20.05 wib. In International Baby Food Action Network (IBFAN) Asia. https://doi.org/10.1007/s12020015-0766-8

Walyani, elysabeth siwi. (2016). Asuhan Kebidanan Kehamilan.
Kementrian Kesehatan Republik Indonesia.

Walyani, E. S., \& Purwoastuti, E. (2016). Asuhan Persalinan dan Bayi Baru Lahir. In Yogyakarta. 